This is the peer-reviewed version of the article:

Kukić, J.; Popović, V.; Petrović, S.; Mucaji, P.; Ćirić, A.; Stojković, D.; Soković, M. Antioxidant and Antimicrobial Activity of Cynara Cardunculus Extracts. Food Chem. 2008, 107 (2), 861-868. https://doi.org/10.1016/j.foodchem.2007.09.005

\title{
@
}

This work is licensed under the https://creativecommons.org/licenses/by-nc-nd/4.0/ 


\section{1 Antioxidant and Antimicrobial Activity of}

\section{Cynara cardunculus Extracts}

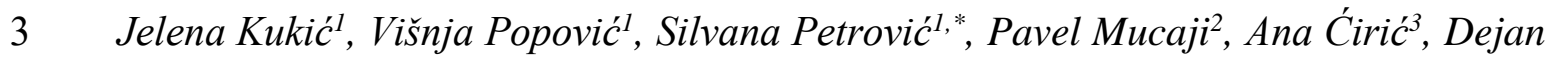

$6{ }^{1}$ Institute of Pharmacognosy, Faculty of Pharmacy, Vojvode Stepe 450, 11221 Belgrade, Serbia

${ }^{2}$ Department of Pharmacognosy and Botany, Pharmaceutical Faculty, Comenius University, Odbojarov 10, 83232, Bratislava, Slovak Republic Research "Siniša Stanković", Bulevar Despota Stefana 142, 11000 Belgrade, Serbia

${ }^{*}$ Corresponding author. Tel.: +381-11-39-70-379/722; Fax: +381-11-39-72-840.

E-mail address: silvana@pharmacy.bg.ac.yu (S. Petrović) 


\section{Abstract}

13 The whole, fresh involucral bracts of cardoon, Cynara cardunculus L. (Compositae),

14 were extracted with EtOH and aqueous suspension of obtained $\mathrm{EtOH}$ extract was

15 partitioned successively with $\mathrm{CHCl}_{3}$, EtOAc and $n$-BuOH, leaving residual water extract.

16 All obtained extracts were evaluated on their antioxidant and antimicrobial properties.

17 The antioxidant potential was evaluated using following in vitro methods: FRAP (Ferric

18 Reducing Antioxidant Power) assay, and scavenging of 2,2-diphenyl-1-picrylhydrazyl

19 (DPPH) radical. Antimicrobial activity was estimated using microdilution technique 20 against food-borne, mycotoxin producers and human pathogenic bacteria and

21 micromycetes. Following bacteria were tested: Salmonella typhimurium, Escherichia 22 coli, Bacillus subtilis, Staphylococcus epidermidis, Staphylococcus aureus, as well as 23 micromycetes: Aspergillus niger, Aspergillus ochraceus, Aspergillus flavus, Penicillium 24 ochrochloron, Penicillium funiculosum, Trichoderma viride, Fusarium tricinctum and 25 Alternaria alternata. Results showed that all extracts possess concentration dependent 26 antioxidant activity. In biological assays, $C$. cardunculus extracts showed antimicrobial 27 activity comparable with standard antibiotics.

29 Keywords: Cynara cardunculus; Involucral bracts; Antioxidant activity; FRAP; DPPH; 30 Antimicrobial activity 
32 Cardoon or wild artichoke (Cynara cardunculus L., Compositae) is a perennial plant, 33 which shares a recent common ancestor with the modern cultivated "globe" artichoke, $C$. 34 scolymus L. Both plants have their origin in edible Cynara cultivars used by early 35 farmers in the Mediterranean region (Kelly \& Pepper, 1996). Traditional applications of 36 C. cardunculus consider the usage of the blanched leaves, fleshy leaf petioles and the 37 receptacle in soups, stews and salads (do Amaral Franco, 1976; Grieve, 1971; 38 Fernandez, Curt, \& Aguado, 2006). There are reports of usage of its petioles and roots if 39 properly prepared (Kelly \& Pepper, 1996). Flowers of C. cardunculus are rich in 40 proteases, namely cardosins $\mathrm{A}$ and $\mathrm{B}$, due which aqueous extracts of its flowers have 41 been used for centuries in the Iberian Peninsula for manufacturing of ovine and/or 42 caprine milk cheeses (Silva \& Malcata, 2005; Fernandez et al., 2006). Cardoon is 43 traditionally used as a diuretic, choleretic, cardiotonic and an antihemorrhodial (Koubaa, 44 Damak, McKillop, \& Simmonds, 1999). Cardoon leaves are used for their cholagogue, 45 choleretic and choliokinetic actions, for treatment of dyspepsia and as antidiabetics (Paris 46 \& Moyse, 1971; Koubaa et al., 1999).

47 Previous chemical investigations have shown the presence of saponins, sesquiterpene 48 lactones, flavones, sterols, coumarins and lignans in leaves and seeds of C. cardunculus 49 (Valentao, Fernandez, Carvalho, Andrade, Seabra, \& Bastos, 2002; Ševčikova, Glatz, \& 50 Slanina, 2002; Pinelli, Agostini, Comino, Lanteri, Portis, \& Romani, 2007; Koubaa \& 51 Damak, 2003). In involucral bracts of the investigated species were identified sterols, 52 triterpenoid saponins, coumarines, flavonoids and caffeic acid derivatives (Mučaji, 53 Grančai, Nagy, Višňovská, \& Ubik, 2000). 
54 The antioxidant activity of lyophilized aqueous extract of cardoon leaves and against 55 superoxide radical is reported (Valentao et al., 2002). Mono- and dicaffeoylquinic acids 56 which are present in cardoon extracts showed anti-HIV integrase activity (Slanina,

57 Taborska, Bochorakowa, Humpa, Robinson, \& Schram, 2001). Triterpenoid saponins, 58 isolated from involucral bracts of $C$. cardunculus, reduce the chemically induced 59 mutagenesis in vitro (Križkova, Mučaji, Nagy, \& Krajčovič, 2004) and possess 60 anticomplement activity (Mučaji, Bukovsky, Grančai, \& Nagy, 2003). Recent study 61 showed that $C$. cardunculus leaf extract prevents the age-associated loss of vasomotor 62 function (Rossoni, Grande, Galli, \& Visioli, 2005).

63 The objectives of this study were to investigate antioxidant and antimicrobial activity 64 of various extracts from C. cardunculus involucral bracts, as well as activity of some 65 compounds previously isolated from therein.

66

67 2. Material and methods

68 2.1. Chemicals

69 Dimethylsulfoxide (DMSO), 2,2-diphenyl-1-picrylhydrazyl (DPPH), Folin-Ciocalteu 70 reagent, 2,4,6-tris(2-pyridyl)-s-triazine (TPTZ) were obtained from Sigma Chemical Co. 71 (St. Louis, U.S.A.); L-ascorbic acid from Lachema (Neratovice, Czech Republic); 72 Müeller-Hinton agar (MH), Malt agar (MA) from Institute of Immunology and Virology, 73 Torlak (Belgrade, Serbia); streptomycin (Streptomicin-sulfat, ampoules $1 \mathrm{~g}$ ) and 74 miconazole from Galenika, a.d. (Belgrade, Serbia). Standard compounds 1-9, namely: 75 apigenin (1), cynarasaponins $\mathrm{A}+\mathrm{H}$ (2), luteolin 7-glucoside (3), apigenin 7-rutinoside (4), 76 luteolin (5), chlorogenic acid (6), $\beta$-sitosterol (7), cynarasaponins $\mathrm{B}+\mathrm{K}(\mathbf{8})$ and apigenin 
77 7-glucoside (9), were isolated previously from C. cardunculus involucral bracts at the Department of Pharmacognosy and Botany, Pharmaceutical Faculty, Comenius University, in Bratislava.

\subsection{Plant material}

The whole involucral bracts of $C$. cardunculus were collected from plants grown at Medicinal Plants Garden in Bratislava. A voucher specimen was deposited at the Pharmaceutical Faculty, Comenius University, Bratislava.

\subsection{Extraction}

The whole, fresh involucral bracts were cut in pieces and repeatedly extracted with $\mathrm{EtOH}(96 \%, \mathrm{v} / \mathrm{v})$ at room temperature. Aqueous suspension of the concentrated EtOH extract was partitioned successively with $\mathrm{CHCl}_{3}$, EtOAc and $n$-BuOH, leaving residual water extract. All obtained extracts, including residual water extract, were evaporated till dryness and used for all investigations.

\subsection{Determination of total phenolics content}

Total phenolics content was determined using Folin-Ciocalteu (FC) reagent as previously described (Velioglu, Mazza, Gao, \& Oomah, 1998). $100 \mu$ of the extract dissolved in methanol was mixed with $750 \mu \mathrm{l}$ of FC reagent (previously diluted 10 -fold with distilled water) and allowed to stand at $22{ }^{\circ} \mathrm{C}$ for $5 \mathrm{~min} ; 750 \mu \mathrm{l}$ of $\mathrm{Na}_{2} \mathrm{CO}_{3}(60 \mathrm{~g} / \mathrm{l})$ solution was added to the mixture. After 90 min the absorbance was measured at 725 nm. Results were expressed as gallic acid equivalents (mg of gallic acid/mg dry weigh extract). 


\subsubsection{Thin-layer chromatography}

105 Each extract and previously isolated compounds (1-9) were dissolved in appropriate

106 solvent, applied on silica gel plates (Merck, Darmstadt, Germany), and developed using 107 different solvent systems: EtOAc/HCOOH/glacial AcOH/water (100:11:11:26, v/v/v/v), 108 toluene/EtOAc/HCOOH $(5: 4: 1, \quad \mathrm{v} / \mathrm{v} / \mathrm{v})$, and toluene/EtOAc $\quad(7: 3, \quad \mathrm{v} / \mathrm{v})$ system.

109 Components were detected by spraying with NP/PEG reagent (flavonoids, phenolic 110 acids) and with vanillin-sulphuric acid (VS) reagent (saponins and sterols) (Wagner \& 111 Bladt, 1996). DPPH test performed directly on TLC plates (0.2\% DPPH in MeOH (w/v)

112 used as spray reagent) revealed contributions to the antioxidant activity of different 113 compounds separately (Cuendet, Hostettmann, \& Potterat, 1997).

116 Total antioxidant activity (TAA) was investigated using Ferric Reducing Antioxidant

117 Power (FRAP) assay, which is based upon reduction of $\mathrm{Fe}^{3+}-\mathrm{TPTZ}$ complex in acidic

118 conditions. Increase in absorbance of blue colored ferrous form ( $\mathrm{Fe}^{2+}-\mathrm{TPTZ}$ complex) is 119 measured at $593 \mathrm{~nm}$. FRAP reagent was freshly prepared by mixing $25 \mathrm{ml}$ acetate buffer 120 (300 mM, pH 3.6), $2.5 \mathrm{ml}$ TPTZ solution (10 mM TPTZ in $40 \mathrm{mM} \mathrm{HCl})$ and $2.5 \mathrm{ml}$ $121 \mathrm{FeCl}_{3}(20 \mathrm{mM})$ water solution. $100 \mu \mathrm{l}$ of each extract dissolved in appropriate solvent 122 was added in $4.5 \mathrm{ml}$ of FRAP reagent, stirred and incubated for $30 \mathrm{~min}$ absorbance was measured at $593 \mathrm{~nm}$, using FRAP working solution as blank. Calibration curve of ferrous

124 sulfate (100-1000 $\mu \mathrm{M})$ was used, and results were expressed in $\mu \mathrm{mol} \mathrm{Fe}^{2+} / \mathrm{mg}$ dry weight 
125 extract. The relative activity of the samples was compared to L-ascorbic acid (Pellegrini 126 et al., 2003).

\subsubsection{DPPH radical assay}

129 Extracts were dissolved in appropriate solvents, mixed with $1 \mathrm{ml}$ of $0.5 \mathrm{mM} \mathrm{2,2-}$ 130 diphenyl-1-picrylhydrazyl radical (DPPH) in $\mathrm{MeOH}$, and final volume adjusted up to 5 $131 \mathrm{ml}$. Mixtures were virgously shaken and left $30 \mathrm{~min}$ in dark. Absorbance was measured at $132517 \mathrm{~nm}$ using $\mathrm{MeOH}$ as blank. $1 \mathrm{ml}$ of $0.5 \mathrm{mM}$ DPPH diluted in $4 \mathrm{ml}$ of MeOH was used as control. Neutralisation of DPPH radical was calculated using the equation: $\mathrm{S}(\%)=100 \times\left(\mathrm{A}_{0}-\mathrm{A}_{\mathrm{s}}\right) / \mathrm{A}_{0}$, where $\mathrm{A}_{0}$ is the absorbance of the control (containing all reagents except the test compound), and $\mathrm{A}_{\mathrm{s}}$ is the absorbance of the tested sample. The $\mathrm{SC}_{50}$

136 value represented the concentration of the extract that caused $50 \%$ of neutralisation

137 (Cuendet et al., 1997). Results were compared with the activity of L-ascorbic acid.

141 In order to obtain quantitative data for extracts and previously isolated compounds (1-

142 9), the modified microdilution technique was used (Hanel \& Raether, 1988; Daouk, 143 Dagher, \& Sattout, 1995). The following bacteria were tested: Salmonella typhimurium 144 (ATCC 13311), Escherichia coli (ATCC 35210), Bacillus subtilis (ATCC 10907), Staphylococcus epidermidis (ATCC 12228) and Staphylococcus aureus (ATCC 29213).

146 The organisms tested were obtained from Department for Plant Physiology, Institute for

147 Biological Research "Siniša Stanković”, Belgrade, Serbia.

148 The bacterial suspension was adjusted with sterile saline to a concentration of 149 approximately $1.0 \times 10^{7} \mathrm{cell} / \mathrm{ml}$. The inocula were stored at $+4{ }^{\circ} \mathrm{C}$ for further use. 
150 Dilutions of the inocula were cultured on solid Müller-Hinton (MH) agar (Institute of

151 Immunology and Virology, Torlak, Belgrade, Serbia) to verify the absence of

152 contamination and to check the validity of the inoculum.

153 Minimum inhibitory concentrations (MICs) determination was performed by a serial 154 dilution technique using 96-well microtitre plates. The bacterial inocula applied contained 155 approximately $1.0 \times 10^{5}$ cells in a final volume of $100 \mu \mathrm{l} /$ well. The extracts and 156 compounds tested were dissolved in DMSO (0.1-1.0 mg/ml) and added in broth medium

157 with bacterial inocula. The microplates were incubated for $24 \mathrm{~h}$ at $37{ }^{\circ} \mathrm{C}$. The lowest 158 concentrations without visible growth (at the binocular microscope) were defined as 159 concentrations which completely inhibited bacterial growth (MICs). The minimum 160 bactericidal concentrations (MBCs) were determined by serial subcultivation of a $2 \mu 1$ 161 into microtitre plates containing $100 \mu \mathrm{l}$ of broth per well and further incubation for $24 \mathrm{~h}$ 162 at $37{ }^{\circ} \mathrm{C}$. The lowest concentration with no visible growth was defined as the $\mathrm{MBC}$, 163 indicating $\geq 99.5 \%$ killing of the original inoculum. DMSO was used as a negative

164 control, while streptomycin was used as a positive control $(0.5-2.0 \mu \mathrm{g} / \mathrm{ml})$. Dilutions of 165 the inocula were also cultured on solid MH to verify the absence of contamination and to 166 check their validity.

\subsubsection{Test on antifungal activity}

169 Antifungal activity of the extracts and previously isolated compounds (1-9) was 170 investigated using modified microdilution technique (Hanel \& Raether, 1988; Daouk et 171 al., 1995). For the bioassays eight fungi were tested: Aspergillus niger (ATCC 6275), 172 Aspergillus ochraceus (ATCC 12066), Aspergillus flavus (ATCC 9643), Penicillium 173 ochrochloron (ATCC 9112), Penicillium funiculosum (ATCC 36839), Trichoderma 
175 2006). The organisms tested were obtained from the Mycological Laboratory,

176 Department of Plant Physiology, Institute for Biological research "Siniša Stanković",

177 Belgrade, Serbia. The micromycetes were maintained on malt agar (MA) the cultures

178 were stored at $+4{ }^{\circ} \mathrm{C}$ and subcultured once a month (Booth, 1971).

179 The fungal spores were washed from the surface of agar plates with sterile $0.85 \%$

180 saline containing $0.1 \%$ Tween $80(\mathrm{v} / \mathrm{v})$. The spore suspension was adjusted with sterile

181 saline to a concentration of approximately $1.0 \times 10^{5}$ in a final volume of $100 \mu 1 /$ well. The

182 inocula were stored at $+4{ }^{\circ} \mathrm{C}$ for further use. Dilutions of the inocula were cultured on

183 solid MA to verify the absence of contamination and to check the validity of the 184 inoculum.

185 Minimum inhibitory concentrations (MICs) determination was performed by a serial 186 dilution technique using 96-well microtitre plates. The compounds and extracts 187 investigated were dissolved in DMSO $(0.1-1.0 \mathrm{mg} / \mathrm{ml})$ and added in broth malt medium 188 with fungal inoculum. The microplates were incubated for $72 \mathrm{~h}$ at $28{ }^{\circ} \mathrm{C}$. The lowest 189 concentrations without visible growth (at the binocular microscope) were defined as 190 MIC. The minimum fungicidal concentrations (MFCs) were determined by serial 191 subcultivation of a $2 \mu \mathrm{l}$ into microtitre plates containing $100 \mu \mathrm{l}$ of malt broth per well and 192 further incubation for $72 \mathrm{~h}$ at $28{ }^{\circ} \mathrm{C}$. The lowest concentration with no visible growth 193 was defined as the MFC, indicating $\geq 99.5 \%$ killing of the original inoculum. DMSO was 194 used as a negative control, while miconazole was used as a positive control $(0.1-5.0$ $195 \mu \mathrm{g} / \mathrm{ml})$. 
The results of the experiments were analyzed by two factorial analysis of variance

199 (ANOVA). The Package program Statistica (release 4.5, Copyright StatSoft, Inc. 1993)

was used for statistical evaluation. Antioxidant activity and determination of total

phenolics content were run in triplicates. Experiments on antimicrobial activity were replicated twice on same occasions. All analyses were run in triplicate for each replicate $(n=2 \times 3)$.

\section{Results}

Total phenolics content was $0.203,0.062,0.050,0.046$ and $0.026 \mathrm{mg}$ of gallic acid

207 equivalent/mg dry weigh for EtOAc, $n$ - $\mathrm{BuOH}$, EtOH, water and $\mathrm{CHCl}_{3}$ extracts of $C$. 208 cardunculus whole involucral bracts, respectively (Table 1).

209 Total antioxidant activity (TAA) of the investigated extracts was $0.38,0.36,0.35,0.34$

210 and $0.12 \mu \mathrm{mol} \mathrm{Fe} \mathrm{Fe}^{2+} / \mathrm{mg}$ dry weigh for EtOAc, $n$-BuOH, $\mathrm{EtOH}$, water and $\mathrm{CHCl}_{3}$

211 extracts, respectively. L-Ascorbic acid used as standard had TAA at $7.41 \mu \mathrm{mol} \mathrm{Fe} \mathrm{Fe}^{2+} / \mathrm{mg}$

212 (Table 1). Scavenging of DPPH radical was concentration-dependent. EtOAc extract

213 expressed the strongest activity $\left(\mathrm{SC}_{50}=21.50 \mu \mathrm{g} / \mathrm{ml}\right)$, while $n-\mathrm{BuOH}, \mathrm{EtOH}$ and water

214 extracts showed moderate activity $\left(\mathrm{SC}_{50}=127.10, \quad 157.00\right.$ and $173.15 \mu \mathrm{g} / \mathrm{ml}$,

215 respectively). $\mathrm{CHCl}_{3}$ extract did not reach $50 \%$ of $\mathrm{DPPH}$ neutralisation at the highest

216 concentration applied (Table 1).

217 TLC-DPPH test showed that phenolic compounds were the main antioxidant 218 components in the investigated extracts. The most prominent anti-DPPH zones were 219 revealed only few seconds after spraying with DPPH reagent, in chromatograms of 220 EtOAc, $n$-BuOH and EtOH extracts. According to applied standards, main "scavengers" 221 were apigenin (1), luteolin (5), apigenin 7-glucoside (9), and luteolin 7-glucoside (3) 222 previously isolated from EtOAc extract (Grančai, Nagy, Suchý, \& Ubik, 1993), as well 
as apigenin 7-rutinoside (4) and chlorogenic acid (6) from $n$-BuOH extract (Grančai,

Mučaji, Nagy, \& Ubik, 1996; Mučaji et al., 2000). Cynarasaponins (2, 8) previously

isolated from $n$-BuOH extract (Mučaji, Grančai, Nagy, Buděšínský, \& Ubik, 1999;

Mučaji, Grančai, Nagy, Buděšínský, \& Ubik, 2001), and $\beta$-sitosterol (7) from $\mathrm{CHCl}_{3}$ extract (Grančai, Nagy, Suchý, \& Ubik, 1992), did not express any scavenging activity.

The results of testing of antibacterial activity of $C$. cardunculus extracts showed that

EtOAc extract was the most effective (with MICs of 1.0-1.5 mg/ml and MBCs 1.5-2.0

$\mathrm{mg} / \mathrm{ml}$ ), followed by $\mathrm{EtOH}, \mathrm{CHCl}_{3}$, water and $n$-BuOH extracts. S. typhimurium was

found to be the most resistant species with MICs of 1.5-2.0 mg/ml and MBCs of 2.0-2.5

$\mathrm{mg} / \mathrm{ml}$. E. coli was the most sensitive with MICs of $1.0-1.5 \mathrm{mg} / \mathrm{ml}$ and MBCs of 1.5-2.0

$\mathrm{mg} / \mathrm{ml}$. Commercial drug streptomycin showed higher antibacterial potency than extracts

tested (Table 2). Considering antifungal potential of investigated $C$. cardunculus extracts, EtOAc extract was also the most effective one with values of MICs and MFCs in equal range of 1.0-1.5 $\mathrm{mg} / \mathrm{ml}$ (Table 3). Miconazole showed stronger antifungal activity then extracts tested. As for the standard compounds, the uppermost antibacterial, as well as the highest antifungal activity was observed by luteolin (5) with MICs and MBCs ranged from $0.05-0.10 \mathrm{mg} / \mathrm{ml}$, and MICs and MFCs ranged from 0.03-0.10 mg/ml (Tables 4 and 5).

\section{Discussion}

243 Many studies report the polyphenolic composition of cultivated and wild artichokes.

244 The major class of polyphenols in C. scolymus are caffeic acid derivatives (Mulinacci et 245 al., 2004) which, in heads, mainly occur as esters with quinic acid; leaves and heads of 246 globe artichoke have been also found to be rich in mono- and dicaffeoylquinic 247 compounds and flavonoids (Alamanni \& Cossu, 2003; Wang, Simon, Fabiola Aviles, He, 
De Palma, Pepe, \& Nazzaro, 2007; Pinelli et al., 2007). As for cardoon, C. cardunculus, there are reports on phenolic composition of their leaves: caffeoylquinic acids and glycosides of luteolin and apigenin were identified using HPLC (Valentao et al., 2002; Pinelli et al., 2007). In the involucral bracts of this plant various compounds were also

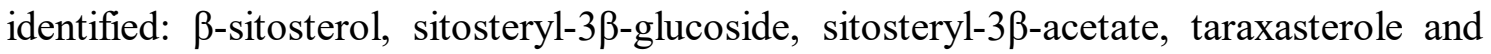
taraxasteryl-3ß-acetate (Grančai et al., 1992), apigenin, apigenin 7-glucoside, luteolin and luteolin 7-glucoside (Grančai et al., 1993), apigenin 7-rutinoside, luteolin 7rutinoside (Grančai et al., 1996), and apigenin 7-methylglucuronide (Mučaji, et al., 2000), scopolin and scopoletin (Grančai, Nagy, Mučaji, Suchý, \& Ubik, 1994a), cynarin (Grančai, Nagy, Suchý, \& Novomeský, 1994b) and chlorogenic acid (Mučaji et al., 2000), cynarasaponins A and H, and their methyl derivatives (Mučaji et al., 1999), and cynarasaponins B and K (Mučaji et al., 2001).

As previously showed, apigenin, luteolin and their glycosides are powerful antioxidants (Kwon, Kim, Kim, Kim, \& Kim, 2002; Müller, Vasconcelos, Coelho, \& Biavatti, 2005). The antioxidant effectiveness of apigenin was determined in models such as the in vitro lipoprotein oxidation model (Vinson, Dabbagh, Serry, \& Jang, 1995). The antioxidant properties of luteolin 7-glucoside and of the respective aglycon, luteolin, have already been observed against low-density lipoprotein oxidation (Brown \& Rice-Evans, 1998),

267 DPPH free radical scavenging activity and $\mathrm{ABTS}^{\cdot+}$ radical cation scavenging effect 268 (Wang et al., 1998).

269 Chlorogenic acid is one of the most abundant phenolic acids in various plant extracts 270 and also the most active antioxidant constituent. It has been shown that the antioxidant 271 activities of 3-O-caffeoylquinic acid and 4-O-caffeoylquinic acid are almost the same as 272 chlorogenic acid when assayed for scavenging activity on superoxide anion radicals and 
inhibitory effect against oxidation of methyl linoleate (Takeoka \& Dao, 2003). 3,4-Di- $O$ caffeoylquinic acid, 3,5-di- $O$-caffeoylquinic acid, along with chlorogenic acid inhibited lipid peroxidation and exhibit neuroprotective activities (Nakajima, Shimazawa, Mishima, \& Hara, 2007).

$\beta$-Sitosterol generally showed low antioxidant activity, comparing to different

278 phenolics such as flavonoids, caffeic and chlorogenic acid, but it exhibited a higher lipid 279 peroxidation inhibition rate (Yokota et al., 2006). Antioxidant activity of $\beta$-sitosterol determined by the oxidative stability instrument (OSI) was considerable (Weng \& Wang, 2000), and even much stronger than that of $\alpha$-tocopherol (Jiang \& Wang, 2006). It was suggested that $\beta$-sitosterol, which inhibits active oxygen produced by neutrophyls, exerts its antioxidative action through a preventive action, such as stabilization of the cell

284 membrane. Caffeic acid derivatives and polyphenols that capture hydroxyl and superoxyde anion radicals act as radical scavengers, while $\beta$-sitosterol exerts a preventive action by inhibiting the excess production of active oxygen by various cells (Yokota et al., 2006).

Results of our experiments are consistent with previous data reported (Alamanni \& Cossu, 2003). As main antioxidant compounds in investigated C. cardunculus extracts we identified flavones: apigenin and luteolin, and their glycosides, as well as chlorogenic acid. The highest antioxidant activity of the EtOAc extract could be explained, among other, by presence of apigenin and luteolin in significantly larger amount than in other extracts.

Our experiments presented substantial antimicrobial activity of $C$. cardunculus involucral bracts extracts with MICs, MBCs and MFCs of 1.00-2.50 mg/ml. EtOAc extract was again the most effective. 

concentrations of $5 \mathrm{mg} / \mathrm{ml}$, completely inhibited the growth with a bactericidal effect on

Staphylococcus aureus, Bacillus cereus and B. subtilis. Zhu, Zhang, and Lo (2004)

302 fractions. Similar investigations were done with successive $\mathrm{CHCl}_{3}, \mathrm{EtOH}$, and EtOAc

303 partitions of extracts of C. scolymus leaf, head, and stem. The MIC values for fungi were at or below $2.5 \mathrm{mg} / \mathrm{ml}$ and for bacteria were at or above $2.5 \mathrm{mg} / \mathrm{ml}$ (Zhu, Zhang, Lo, \& Lu, 2005).

The results of our experiment showed that all standard compounds, previously

307 isolated from involucral bracts of $C$. cardunculus, possess antimicrobial activity against 308 all tested strains of bacteria and fungi (MICs, MBCs and MFCs in a range of 0.03-0.10 $309 \mathrm{mg} / \mathrm{ml}$ ). Among them, luteolin showed the best activity.

310 Similar results were also previously observed with compounds isolated from $C$. 311 scolymus leaves. Among them, chlorogenic acid, cynarin, luteolin 7-rutinoside, and 312 cynaroside exhibited a relatively higher activity than other compounds and were more

313 effective against fungi than against bacteria, with MICs ranged from $0.05-0.20 \mathrm{mg} / \mathrm{ml}$

314 (Zhu et al., 2004). Antimicrobial activity of apigenin, apigenin 7-glucoside, luteolin and 315 other flavones has been also previously reported (Aljančić et al., 1999; Tshikalange, 316 Meyer, \& Hussein, 2005).

317 Herein obtained results on antioxidant and antimicrobial activity of different extracts of

318 C. cardunculus involucral bracts supported the traditional medicinal use of this plant and 319 provided grounds for its further establishing as a functional food. 
ABBREVIATIONS USED: ATCC, American Type of Culture Collection; $n$-BuOH, n-butanol; CBS, Centraalbureau voor Schimmelcultures, Baarn, The Netherlands;

$322 \mathrm{CHCl}_{3}$, chloroform; DMSO, dimethylsulfoxide; DPPH, 2,2-diphenyl-1-picrylhydrazyl;

323 DSM, Deutsche Sammlung von Mikroorganismen; EDTA, ethylenediaminetetraacetic

324 acid; EtOAc, ethyl acetate; EtOH, ethanol; FC reagent, Folin-Ciocalteu reagent; FRAP 325 assay, Ferric reducing antioxidant power assay; IAM, Institute of Applied Microbiology,

326 University of Tokyo, Japan; MA, malt agar; MBC, minimum bactericidal concentration;

$327 \mathrm{MeOH}$, methanol; MFC, minimum fungicidal concentration; MH, Müller-Hinton; MIC, 328 minimum inhibitory concentration; NP/PEG reagent, natural products-polyethylene 329 glycol reagent; TAA, total antioxidant activity; TPTZ, 2,4,6-tris(2-pyridyl)-s-triazine.

331 ACKNOWLEDGMENT. This research was supported by the Ministry of Science 332 and Environmental Protection of Republic of Serbia (Grants № 143012 and 143041). 


\section{LITERATURE CITED}

Alamanni, M. C., \& Cossu, M. (2003). Antioxidant activity of the extracts of the edible part of artichoke (Cynara scolimus L.) var. spinoso sardo. Italian Journal of Food Science, 15, 187-195.

Aljančić, I., Vajs, V., Menković, N., Karadžić, I., Juranić, N., Milosavljević, S., \& Macura, S. (1999). Flavones and sesquiterpene lactones from Achillea atrata subsp. multifida: antimicrobial activity. Journal of Natural Products, 62, 909-911.

Booth, C. (1971). Fungal Culture Media. In J. R. Norris, \& D. W. Ribbons, Methods in Microbiology, (pp. 49-94). London \& New York: Academic Press.

Brown, J. E., \& Rice-Evans, C. A. (1998). Luteolin-rich artichoke extract protects lowdensity lipoprotein from oxidation in vitro. Free Radical Research, 29, 247-255.

Cuendet, M., Hostettmann, K., \& Potterat, O. (1997). Iridoid glucosides with free radical scavenging properties from Fagraea blumei. Helvetica Chimica Acta, 80, 1144-1152.

Daouk, R. K., Dagher, S. M., \& Sattout, J. E. (1995). Antifungal activity of the Essential oil of Origanum syriacum L. Journal of Food Protection, 58, 1147-1149.

do Amaral Franco, J. (1976). Cynara L. In T. G. Tutin, V. H. Heywood, N. A. Burges, D. M. Moore, D. H. Valentine, S. M. Walters, \& D. A. Webb, Flora Europaea, vol. 4 (pp 248-249). Cambridge: Cambridge Unversity Press.

Fernandez, J., Curt, M. D., \& Aguado, P. L. (2006). Industrial applications of Cynara cardunculus L. for energy and other uses. Industrial Crops and Products, 24, 222229. 
Fratianni, F., Tucci, M., De Palma, M., Pepe, R., \& Nazzaro, F. (2007). Polyphenolic composition in different parts of some cultivars of globe artichoke (Cynara cardunculus L. var. scolymus (L.) Fiori). Food Chemistry, 104, 1282-1286.

Grančai, D., Nagy, M., Suchý, V., \& Ubik, K. (1992). Constituents of Cynara cardunculus L. I. Sterols and pentacyclic triterpens. Farmaceutický Obzor, 61, 577580.

Grančai, D., Nagy, M., Suchý, V., \& Ubik, K. (1993). Constituents of Cynara cardunculus L. II. Flavonoids. Farmaceutický Obzor, 62, 31-33.

Grančai, D., Nagy, M., Mučaji, P., Suchý, V., \& Ubik, K. (1994a). Constituents of Cynara cardunculus L. III. Coumarins. Farmaceutický obzor, 63, 447-449.

Grančai, D., Nagy, M., Suchý, V., \& Novomeský, P. (1994b). Cynarin from the fresh flower buds of Cynara cardunculus. Fitoterapia, 65, 282.

Grančai, D., Mučaji, P., Nagy, M., \& Ubik, K. (1996). Constituents of Cynara cardunculus L. IV. Flavonoid glycosides. Farmaceutický obzor, 65, 255-256.

Grieve M. (1971). A Modern Herbal. New York: Dover Publications, Inc.

Hanel, H., \& Raether, W. (1998). A more sophisticated method of determining the fungicidal effect of water-insoluble preparations with a cell harvester, using miconazole as an example. Mycoses, 31, 148-154.

Jiang, A., \& Wang, C. (2006). Antioxidant properties of natural components from Salvia plebeia on oxidative stability of ascidian oil. Process Biochemistry, 41, 1111-1116. 
375 Kelly, M., \& Pepper, A. (1996). Controlling Cynara cardunclus (Artichoke Thistle, 376 Cardoon, etc.). In J. E. Lovich, J. Randall, \& M. D. Kelly, Proceedings of the 377 California Exotic Pest Plant Council Symposium, vol. 2 (pp. 97-101). San Diego: $378 \quad$ California Exotic Pest Plant Council.

379 Koubaa, I., Damak, M., McKillop, A., \& Simmonds, M. (1999). Constituents of Cynara $380 \quad$ cardunculus. Fitoterapia, 70, 212-213.

381 Koubaa, I., \& Damak, M. (2003). A new dilignan from Cynara cardunculus. 382 Fitoterapia, 74, 18-22.

383 Križkova, L., Mučaji, P., Nagy, M., \& Krajčovič, J. (2004). Triterpenoid cynarasaponins 384 from Cynara cardunculus L. reduce chemicaly induced mutagenesis in vitro. 385 Phytomedicine, 11, 673-678.

Kwon, Y. S., Kim, E. Y., Kim, W. J., Kim, W. K., \& Kim, C. M. (2002). Antioxidant 387 constituents from Setaria viridis. Archives of Pharmacal Research 25, 300-305.

Mossi, A. J., \& Echeverrigaray, S. (1999). Identification and characterization of antimicrobial components in leaf extracts of globe artichoke (Cynara scolymus L.). Acta Horticulturae, 501, 111-114.

Mučaji, P., Grančai, D., Nagy, M., Buděšínský, M., \& Ubik, K. (1999). Triterpenoid saponins from Cynara cardunculus L. Pharmazie, 54, 714-716.

393 Mučaji, P., Grančai, D., Nagy, M., Višňovská, Z., \& Ubik, K. (2000). Apigenin-7394 methylglucuronide from Cynara cardunculus L. Česká a slovenská farmacie, 49, 395 $75-77$. 
Mučaji, P., Grančai, D., Nagy, M., Buděšínský, M., \& Ubik, K. (2001). Monodesmosidic saponins from Cynara cardunculus L. Česká a slovenská farmacie, 50, 277-279.

Mučaji, P., Bukovsky, M., Grančai, D., \& Nagy, M. (2003). Anticomplement activity of saponins from Cynara cardunculus L. Česká a slovenská farmacie, 52, 306-309.

Mulinacci, N., Prucher, D., Peruzzi, M., Romani, A., Pinelli, P., Giaccherini, C., \& Vincieri, F. F. (2004). Commercial and laboratory extracts from artichoke leaves: estimation of caffeoyl esters and flavonoidic compounds content. Journal of Pharmaceutical and Biomedical Analysis, 34, 349-357.

Müller, S. D., Vasconcelos, S. B., Coelho, M., \& Biavatti, M. W. (2005). LC and UV determination of flavonoids from Passifora alata medicinal extracts and leaves. Journal of Pharmaceutical and Biomedical Analysis, 37, 399-403.

Nakajima, Y., Shimazawa, M., Mishima, S., \& Hara, H. (2007). Water extract of propolis and its main constituents, caffeoylquinic acid derivatives, exert neuroprotective effects via antioxidant actions. Life Sciences, 80, 370-377.

Paris, R., \& Moyse, H. (1971). Précis de matière médicale, tome III. Paris: Masson et $\mathrm{C}^{\mathrm{ie}}$.

412 Pellegrini, N., Serafini, M., Colombi, B., Del Rio, D., Salvatore, S., Bianchi, M., \& 413 Brighenti, F. (2003). Total antioxidant capacity of plant foods, beverages and oils 414 consumed in Italy assessed by three different in vitro assays. Journal of Nutrition, 133, 2812-2818. 
416 Pinelli, P., Agostini, F., Comino, C., Lanteri, S., Portis, E., \& Romani, A. (2007).

417 Simultaneous quantification of caffeoyl esters and flavonoids in wild and cultivated

418 cardoon leaves, Food Chemistry, doi: 10.1016/j.foodchem.2007.05.014.

419 Rossoni, G., Grande, S., Galli, C., \& Visioli, F. (2005). Wild artichoke prevents age 420 associated loss of vasomotor function. Journal of Agricultural and Food Chemistry, $53,10291-10296$.

422

423

424

425

426

427

428

429

430

431

Schutz, K., Kammerer, D., Carle, R., \& Schieber, A. (2004). Identification and quantification of caffeoylquinic acids and flavonoids from artichoke (Cynara scolymus L.) heads, juice, and pomace by HPLC-DAD-ESI/MSn. Journal of Agricultural and Food Chemistry, 52, 4090-4096.

Silva, S. V., \& Malcata, F. X. (2005). Studies pertaining to coagulant and proteolytic activities of plant proteases from Cynara cardunculus. Food Chemistry, 89, 19-26.

Slanina, J., Taborska, E., Bochorakowa, H., Humpa, O., Robinson, W. E., \& Schram, K. H. (2001). New and facile method of preparation of the anti-HIV agent 1,3dicaffeoylquinic acid. Tetrahedron Letters, 42, 3383-3385.

Sroka, Z., \& Cisowski, W. (2003). Hydrogen peroxide scavenging, antioxidant and antiradical activity of some phenolic acids. Food and Chemical Toxicology, 41, 753758.

Ševčikova, P., Glatz, Z., \& Slanina, J. (2002). Analysis of artichoke extracts (Cynara cardunculus L.) by means of micellar electrokinetics capillary chromatography. Electrophoresis, 23, 249-252. 
Takeoka, G. R., \& Dao, L. T. (2003). Antioxidant constituents of almond [Prunus dulcis (Mill.) D.A. Webb] hulls. Journal of Agricultural and Food Chemistry, 51, 496501.

Tshikalange, T. E., Meyer, J. J. M., \& Hussein, A. A. (2005). Antimicrobial activity, toxicity and the isolation of a bioactive compound from plants used to treat sexually transmitted diseases. Journal of Ethnopharmacology 96, 515-519.

Valentao, P., Fernandes, E., Carvalho, F., Andrade, P. B., Seabra, R. M., \& Bastos, M. L. (2002). Antioxidative properties of cardoon (Cynara cardunculus L.) infuzion against superoxide radical, hydroxyl radical and hypochlorous acid. Journal of Agricultural and Food Chemistry, 50, 4989-4993.

Velioglu, Y. S., Mazza, G., Gao, L., \& Oomah, B. D. (1998). Antioxidant activity and total phenolics in selected fruits, vegetables, and grain products. Journal of Agricultural and Food Chemistry, 46, 4113-4117.

Vinson, J. A., Dabbagh, Y. A., Serry, M. M., \& Jang, J. (1995). Plant flavonoids, especially tea flavonols, are powerful antioxidants using an in vitro oxidation model for heart disease. Journal of Agricultural and Food Chemistry, 43, 2800-2802.

Wagner, H., \& Bladt, S. (1996). Plant Drug Analysis. A Thin Layer Chromatography Atlas, 2nd edition. Berlin-Heidelberg: Springer-Verlag.

Wang, M., Li, J., Rangarajan, M., Shao, Y., La Voie, E. J., Huang, T.-C., \& Ho, C.-T. (1998). Antioxidative phenolic compounds from sage (Salvia officinalis). Journal of Agricultural and Food Chemistry, 46, 4869-4873. 
458 Wang, M., Simon, J. E., Fabiola Aviles, I., He, K., Zheng, Q.-Y., \& Tadmor, Y. (2003).

459 Analysis of antioxidative phenolic compounds in artichoke (Cynara scolymus L.).

$460 \quad$ Journal of Agricultural and Food Chemistry, 51, 601-608.

461 Weng, X. C., \& Wang, W. (2000). Antioxidant activity of compounds isolated from $462 \quad$ Salvia plebeia. Food Chemistry, 71, 489-493.

463 Zhu, X., Zhang, H., \& Lo, R. (2004). Phenolic compounds from the leaf extract of 464 artichoke (Cynara scolymus L.) and their antimicrobial activities. Journal of $465 \quad$ Agricultural and Food Chemistry, 52, 7272-7278.

466 Zhu, X., Zhang, H., Lo, R., \& Lu, Y. (2005). Antimicrobial activities of Cynara 467 scolymus L. leaf, head, and stem extracts. Journal of Food Science, 70, M149468 M152. 
469 Table 1. Antioxidant activity and total phenolics content of Cynara cardunculus extracts

\begin{tabular}{lccc}
\hline Extract & FRAP value $^{\mathrm{a}}$ & DPPH scavenging & \\
\hline EtOAc & Total phenolics content $^{\mathrm{c}}$ \\
$\mathrm{BuOH}$ & $0.38 \pm 0.01$ & $21.50 \pm 1.87$ & $0.203 \pm 0.018$ \\
$\mathrm{EtOH}$ & $0.36 \pm 0.01$ & $127.10 \pm 0.88$ & $0.062 \pm 0.019$ \\
$\mathrm{H}_{2} \mathrm{O}$ & $0.35 \pm 0.01$ & $157.00 \pm 0.16$ & $0.050 \pm 0.010$ \\
$\mathrm{CHCl}_{3}$ & $0.34 \pm 0.01$ & $173.15 \pm 0.65$ & $0.046 \pm 0.007$ \\
\hline L-ascorbic acid & $0.12 \pm 0.02$ & - & $0.026 \pm 0.002$ \\
\hline
\end{tabular}

\footnotetext{
${ }^{\mathrm{a}}$ in $\mu \mathrm{mol} \mathrm{Fe}{ }^{2+} / \mathrm{mg}$ dry weigh extract, ${ }^{\mathrm{b}} \mathrm{SC}_{50}, \mu \mathrm{g} / \mathrm{ml},{ }^{\mathrm{c}} \mathrm{mg}$ of gallic acid equivalent $/ \mathrm{mg}$ dry weigh extract
} 
472 Table 2. Minimum inhibitory and bactericidal concentrations (MICs and MBCs) of

473 Cynara cardunculus extracts (mg/ml)

\begin{tabular}{|c|c|c|c|c|c|c|c|}
\hline \multirow{2}{*}{ Bacteria } & & \multicolumn{5}{|c|}{ Extracts } & \multirow{2}{*}{ Streptomycin } \\
\hline & & $\mathrm{BuOH}$ & EtOH & EtOAc & $\mathrm{CHCl}_{3}$ & $\mathrm{H}_{2} \mathrm{O}$ & \\
\hline \multirow{2}{*}{$\begin{array}{l}\text { S. } \\
\text { typhimurium }\end{array}$} & MIC & $2.0 \pm 0.2$ & $1.5 \pm 0.0$ & $1.5 \pm 0.0$ & $2.0 \pm 0.2$ & $2.0 \pm 0.1$ & $0.0010 \pm 0.0002$ \\
\hline & MBC & $2.5 \pm 0.3$ & $2.0 \pm 0.2$ & $2.0 \pm 0.2$ & $2.5 \pm 0.3$ & $2.0 \pm 0.1$ & $0.0010 \pm 0.0002$ \\
\hline \multirow{2}{*}{ E. coli } & MIC & $1.0 \pm 0.0$ & $1.0 \pm 0.0$ & $1.0 \pm 0.0$ & $1.5 \pm 0.0$ & $1.0 \pm 0.0$ & $0.0005 \pm 0.0001$ \\
\hline & $\mathrm{MBC}$ & $1.5 \pm 0.2$ & $1.5 \pm 0.0$ & $1.5 \pm 0.0$ & $2.0 \pm 0.2$ & $1.5 \pm 0.1$ & $0.0010 \pm 0.0002$ \\
\hline \multirow{2}{*}{ S. epidermidis } & MIC & $1.5 \pm 0.0$ & $1.5 \pm 0.0$ & $1.5 \pm 0.1$ & $1.5 \pm 0.0$ & $1.5 \pm 0.0$ & $0.0010 \pm 0.0000$ \\
\hline & MBC & $2.0 \pm 0.2$ & $2.0 \pm 0.2$ & $2.0 \pm 0.2$ & $2.0 \pm 0.2$ & $2.0 \pm 0.2$ & $0.0010 \pm 0.0000$ \\
\hline \multirow{2}{*}{ S. aureus } & MIC & $1.5 \pm 0.0$ & $1.5 \pm 0.0$ & $1.5 \pm 0.0$ & $1.5 \pm 0.0$ & $1.5 \pm 0.0$ & $0.0010 \pm 0.0002$ \\
\hline & MBC & $2.0 \pm 0.2$ & $2.0 \pm 0.2$ & $2.0 \pm 0.2$ & $2.0 \pm 0.2$ & $2.0 \pm 0.2$ & $0.0010 \pm 0.0003$ \\
\hline \multirow{2}{*}{ B. subtilis } & MIC & $2.0 \pm 0.2$ & $2.0 \pm 0.2$ & $1.0 \pm 0.0$ & $1.5 \pm 0.0$ & $1.0 \pm 0.0$ & $0.0005 \pm 0.0000$ \\
\hline & MBC & $2.5 \pm 0.0$ & $2.0 \pm 0.0$ & $1.0 \pm 0.0$ & $2.0 \pm 0.2$ & $1.0 \pm 0.0$ & $0.0005 \pm 0.0002$ \\
\hline
\end{tabular}

474

475 
476 Table 3. Minimum inhibitory and fungicidal concentrations (MICs and MFCs) of Cynara

477 cardunculus extracts $(\mathrm{mg} / \mathrm{ml})$

\begin{tabular}{|c|c|c|c|c|c|c|c|}
\hline \multirow{2}{*}{ Fungal species } & & \multicolumn{5}{|c|}{ Extracts } & \multirow{2}{*}{ Miconazole } \\
\hline & & $\mathrm{BuOH}$ & $\mathrm{EtOH}$ & EtOAc & $\mathrm{CHCl}_{3}$ & $\mathrm{H}_{2} \mathrm{O}$ & \\
\hline \multirow{2}{*}{ A. flavus } & MIC & $1.5 \pm 0.2$ & $1.5 \pm 0.0$ & $1.5 \pm 0.0$ & $1.5 \pm 0.2$ & $1.5 \pm 0.2$ & $0.0005 \pm 0.0000$ \\
\hline & MFC & $1.5 \pm 0.2$ & $1.5 \pm 0.0$ & $1.5 \pm 0.2$ & $1.5 \pm 0.0$ & $2.0 \pm 0.0$ & $0.0020 \pm 0.0002$ \\
\hline \multirow{2}{*}{ A. niger } & MIC & $1.5 \pm 0.2$ & $1.5 \pm 0.2$ & $1.5 \pm 0.2$ & $1.5 \pm 0.2$ & $1.5 \pm 0.2$ & $0.0015 \pm 0.0003$ \\
\hline & MFC & $1.5 \pm 0.2$ & $1.5 \pm 0.0$ & $1.5 \pm 0.0$ & $1.5 \pm 0.0$ & $2.0 \pm 0.2$ & $0.0040 \pm 0.0002$ \\
\hline \multirow{2}{*}{ A. ochraceus } & MIC & $1.0 \pm 0.0$ & $1.0 \pm 0.0$ & $1.0 \pm 0.0$ & $1.0 \pm 0.0$ & $1.0 \pm 0.0$ & $0.0015 \pm 0.0002$ \\
\hline & MFC & $1.5 \pm 0.2$ & $1.5 \pm 0.2$ & $1.5 \pm 0.2$ & $1.5 \pm 0.0$ & $1.0 \pm 0.0$ & $0.0040 \pm 0.0004$ \\
\hline \multirow{2}{*}{ P. funiculosum } & MIC & $1.5 \pm 0.1$ & $1.5 \pm 0.2$ & $1.0 \pm 0.0$ & $1.0 \pm 0.0$ & $1.0 \pm 0.0$ & $0.0020 \pm 0.0000$ \\
\hline & MFC & $1.5 \pm 0.2$ & $1.5 \pm 0.2$ & $1.5 \pm 0.2$ & $1.5 \pm 0.2$ & $1.5 \pm 0.2$ & $0.0050 \pm 0.0000$ \\
\hline \multirow{2}{*}{ P. ochrachloron } & MIC & $1.0 \pm 0.0$ & $1.0 \pm 0.0$ & $1.0 \pm 0.0$ & $1.0 \pm 0.0$ & $1.0 \pm 0.0$ & $0.0020 \pm 0.0002$ \\
\hline & MFC & $1.5 \pm 0.2$ & $1.5 \pm 0.1$ & $1.5 \pm 0.2$ & $1.5 \pm 0.2$ & $1.5 \pm 0.2$ & $0.0050 \pm 0.0000$ \\
\hline \multirow{2}{*}{ T. viride } & MIC & $1.5 \pm 0.2$ & $1.5 \pm 0.2$ & $1.0 \pm 0.0$ & $1.0 \pm 0.0$ & $1.0 \pm 0.0$ & $0.0020 \pm 0.0000$ \\
\hline & $\mathrm{MFC}$ & $1.5 \pm 0.0$ & $1.5 \pm 0.2$ & $1.0 \pm 0.0$ & $1.5 \pm 0.2$ & $1.0 \pm 0.0$ & $0.0020 \pm 0.0000$ \\
\hline \multirow{2}{*}{ F. tricinctum } & MIC & $1.5 \pm 0.0$ & $1.5 \pm 0.2$ & $1.0 \pm 0.0$ & $1.5 \pm 0.2$ & $1.0 \pm 0.2$ & $0.0002 \pm 0.0000$ \\
\hline & MFC & $1.5 \pm 0.0$ & $1.5 \pm 0.2$ & $1.5 \pm 0.0$ & $1.5 \pm 0.2$ & $1.5 \pm 0.2$ & $0.0010 \pm 0.0002$ \\
\hline \multirow{2}{*}{ A. alternata } & MIC & $1.5 \pm 0.2$ & $1.5 \pm 0.2$ & $1.0 \pm 0.0$ & $1.5 \pm 0.2$ & $1.0 \pm 0.0$ & $0.0002 \pm 0.0000$ \\
\hline & MFC & $1.5 \pm 0.0$ & $1.5 \pm 0.1$ & $1.0 \pm 0.0$ & $1.5 \pm 0.0$ & $1.0 \pm 0.0$ & $0.0010 \pm 0.0002$ \\
\hline
\end{tabular}


478 Table 4. Minimum inhibitory and bactericidal concentrations (MICs and MBCs) of the compounds tested* (mg/ml)

\begin{tabular}{|c|c|c|c|c|c|c|c|c|c|c|c|}
\hline Bacteria & & 1 & 2 & 3 & 4 & 5 & 6 & 7 & 8 & 9 & Streptomycin \\
\hline \multirow{2}{*}{ S. typhimurium } & MIC & $0.10 \pm 0.02$ & $0.10 \pm 0.00$ & $0.10 \pm 0.00$ & $0.10 \pm 0.02$ & $0.05 \pm 0.00$ & $0.10 \pm 0.02$ & $0.10 \pm 0.00$ & $0.10 \pm 0.00$ & $0.10 \pm 0.02$ & $0.0010 \pm 0.0002$ \\
\hline & $\mathrm{MBC}$ & $0.10 \pm 0.02$ & $0.10 \pm 0.00$ & $0.10 \pm 0.00$ & $0.10 \pm 0.02$ & $0.05 \pm 0.00$ & $0.10 \pm 0.02$ & $0.10 \pm 0.00$ & $0.10 \pm 0.00$ & $0.10 \pm 0.02$ & $0.0010 \pm 0.0002$ \\
\hline \multirow{2}{*}{ E. coli } & MIC & $0.10 \pm 0.00$ & $0.10 \pm 0.02$ & $0.10 \pm 0.02$ & $0.10 \pm 0.00$ & $0.05 \pm 0.02$ & $0.10 \pm 0.02$ & $0.10 \pm 0.02$ & $0.10 \pm 0.02$ & $0.10 \pm 0.00$ & $0.0005 \pm 0.0001$ \\
\hline & MBC & $0.10 \pm 0.00$ & $0.10 \pm 0.02$ & $0.10 \pm 0.00$ & $0.10 \pm 0.00$ & $0.10 \pm 0.00$ & $0.10 \pm 0.02$ & $0.10 \pm 0.02$ & $0.10 \pm 0.02$ & $0.10 \pm 0.00$ & $0.0010 \pm 0.0002$ \\
\hline \multirow{2}{*}{ S. epidermidis } & MIC & $0.15 \pm 0.02$ & $0.15 \pm 0.00$ & $0.15 \pm 0.02$ & $0.15 \pm 0.02$ & $0.10 \pm 0.01$ & $0.15 \pm 0.00$ & $0.15 \pm 0.01$ & $0.15 \pm 0.01$ & $0.15 \pm 0.02$ & $0.0010 \pm 0.0000$ \\
\hline & MBC & $0.20 \pm 0.00$ & $0.20 \pm 0.02$ & $0.20 \pm 0.02$ & $0.20 \pm 0.01$ & $0.10 \pm 0.02$ & $0.20 \pm 0.02$ & $0.20 \pm 0.02$ & $0.20 \pm 0.02$ & $0.20 \pm 0.02$ & $0.0010 \pm 0.0000$ \\
\hline \multirow{2}{*}{ S. aureus } & MIC & $0.15 \pm 0.00$ & $0.15 \pm 0.02$ & $0.15 \pm 0.02$ & $0.15 \pm 0.01$ & $0.05 \pm 0.00$ & $0.15 \pm 0.02$ & $0.15 \pm 0.02$ & $0.15 \pm 0.02$ & $0.15 \pm 0.01$ & $0.0010 \pm 0.0002$ \\
\hline & MBC & $0.20 \pm 0.02$ & $0.20 \pm 0.00$ & $0.20 \pm 0.02$ & $0.20 \pm 0.01$ & $0.05 \pm 0.00$ & $0.20 \pm 0.02$ & $0.20 \pm 0.00$ & $0.20 \pm 0.02$ & $0.20 \pm 0.02$ & $0.0010 \pm 0.0003$ \\
\hline \multirow{2}{*}{ B. subtilis } & MIC & $0.15 \pm 0.02$ & $0.15 \pm 0.00$ & $0.15 \pm 0.00$ & $0.15 \pm 0.02$ & $0.05 \pm 0.00$ & $0.10 \pm 0.00$ & $0.10 \pm 0.02$ & $0.10 \pm 0.00$ & $0.10 \pm 0.00$ & $0.0005 \pm 0.0000$ \\
\hline & MBC & $0.20 \pm 0.02$ & $0.20 \pm 0.02$ & $0.20 \pm 0.02$ & $0.20 \pm 0.00$ & $0.10 \pm 0.02$ & $0.15 \pm 0.02$ & $0.15 \pm 0.02$ & $0.15 \pm 0.00$ & $0.15 \pm 0.02$ & $0.0005 \pm 0.0002$ \\
\hline
\end{tabular}


482 Table 5. Minimum inhibitory and fungicidal concentrations (MICs and MFCs) of the compounds tested* (mg/ml)

\begin{tabular}{|c|c|c|c|c|c|c|c|c|c|c|c|}
\hline Fungal species & & 1 & 2 & 3 & 4 & 5 & 6 & 7 & 8 & 9 & Miconazole \\
\hline \multirow{2}{*}{ A. flavus } & MIC & $0.10 \pm 0.02$ & $0.10 \pm 0.02$ & $0.10 \pm 0.01$ & $0.10 \pm 0.02$ & $0.10 \pm 0.02$ & $0.10 \pm 0.02$ & $0.10 \pm 0.02$ & $0.10 \pm 0.02$ & $0.10 \pm 0.02$ & $0.0005 \pm 0.0000$ \\
\hline & MFC & $0.10 \pm 0.02$ & $0.10 \pm 0.01$ & $0.10 \pm 0.01$ & $0.10 \pm 0.02$ & $0.10 \pm 0.02$ & $0.10 \pm 0.02$ & $0.10 \pm 0.02$ & $0.10 \pm 0.02$ & $0.10 \pm 0.02$ & $0.0020 \pm 0.0002$ \\
\hline \multirow{2}{*}{ A. niger } & MIC & $0.10 \pm 0.01$ & $0.10 \pm 0.02$ & $0.10 \pm 0.02$ & $0.10 \pm 0.02$ & $0.10 \pm 0.02$ & $0.10 \pm 0.02$ & $0.10 \pm 0.02$ & $0.10 \pm 0.02$ & $0.10 \pm 0.02$ & $0.0015 \pm 0.0003$ \\
\hline & MFC & $0.10 \pm 0.01$ & $0.10 \pm 0.02$ & $0.10 \pm 0.02$ & $0.10 \pm 0.02$ & $0.10 \pm 0.02$ & $0.10 \pm 0.02$ & $0.10 \pm 0.02$ & $0.10 \pm 0.02$ & $0.10 \pm 0.02$ & $0.0040 \pm 0.0002$ \\
\hline \multirow{2}{*}{ A. ochraceus } & MIC & $0.10 \pm 0.00$ & $0.10 \pm 0.02$ & $0.10 \pm 0.00$ & $0.10 \pm 0.01$ & $0.05 \pm 0.00$ & $0.10 \pm 0.02$ & $0.10 \pm 0.02$ & $0.10 \pm 0.02$ & $0.10 \pm 0.00$ & $0.0015 \pm 0.0002$ \\
\hline & MFC & $0.10 \pm 0.00$ & $0.10 \pm 0.02$ & $0.10 \pm 0.00$ & $0.10 \pm 0.02$ & $0.10 \pm 0.00$ & $0.10 \pm 0.01$ & $0.10 \pm 0.02$ & $0.10 \pm 0.02$ & $0.10 \pm 0.02$ & $0.0040 \pm 0.0004$ \\
\hline \multirow{2}{*}{ P. funiculosum } & MIC & $0.05 \pm 0.02$ & $0.10 \pm 0.02$ & $0.10 \pm 0.02$ & $0.05 \pm 0.00$ & $0.03 \pm 0.00$ & $0.05 \pm 0.00$ & $0.05 \pm 0.02$ & $0.05 \pm 0.02$ & $0.05 \pm 0.01$ & $0.0020 \pm 0.0000$ \\
\hline & MFC & $0.10 \pm 0.02$ & $0.10 \pm 0.02$ & $0.10 \pm 0.02$ & $0.10 \pm 0.02$ & $0.05 \pm 0.00$ & $0.10 \pm 0.00$ & $0.05 \pm 0.02$ & $0.05 \pm 0.02$ & $0.05 \pm 0.02$ & $0.0050 \pm 0.0000$ \\
\hline \multirow{2}{*}{ P. ochrachloron } & MIC & $0.05 \pm 0.00$ & $0.10 \pm 0.02$ & $0.10 \pm 0.02$ & $0.05 \pm 0.00$ & $0.05 \pm 0.00$ & $0.05 \pm 0.00$ & $0.05 \pm 0.02$ & $0.05 \pm 0.02$ & $0.05 \pm 0.01$ & $0.0020 \pm 0.0002$ \\
\hline & MFC & $0.10 \pm 0.01$ & $0.10 \pm 0.02$ & $0.10 \pm 0.02$ & $0.10 \pm 0.00$ & $0.05 \pm 0.00$ & $0.10 \pm 0.01$ & $0.05 \pm 0.02$ & $0.05 \pm 0.02$ & $0.05 \pm 0.01$ & $0.0050 \pm 0.0000$ \\
\hline \multirow{2}{*}{ T. viride } & MIC & $0.05 \pm 0.00$ & $0.05 \pm 0.00$ & $0.05 \pm 0.00$ & $0.05 \pm 0.00$ & $0.03 \pm 0.00$ & $0.05 \pm 0.00$ & $0.05 \pm 0.00$ & $0.05 \pm 0.01$ & $0.05 \pm 0.02$ & $0.0020 \pm 0.0000$ \\
\hline & MFC & $0.05 \pm 0.00$ & $0.10 \pm 0.02$ & $0.10 \pm 0.01$ & $0.05 \pm 0.00$ & $0.05 \pm 0.00$ & $0.10 \pm 0.01$ & $0.10 \pm 0.00$ & $0.10 \pm 0.02$ & $0.10 \pm 0.02$ & $0.0020 \pm 0.0000$ \\
\hline \multirow{2}{*}{ F. tricinctum } & MIC & $0.05 \pm 0.02$ & $0.05 \pm 0.00$ & $0.05 \pm 0.00$ & $0.05 \pm 0.02$ & $0.05 \pm 0.00$ & $0.05 \pm 0.02$ & $0.05 \pm 0.02$ & $0.05 \pm 0.00$ & $0.05 \pm 0.00$ & $0.0002 \pm 0.0000$ \\
\hline & MFC & $0.10 \pm 0.02$ & $0.10 \pm 0.02$ & $0.10 \pm 0.00$ & $0.10 \pm 0.02$ & $0.10 \pm 0.01$ & $0.10 \pm 0.02$ & $0.10 \pm 0.02$ & $0.10 \pm 0.00$ & $0.10 \pm 0.02$ & $0.0010 \pm 0.0002$ \\
\hline \multirow{2}{*}{ A. alternata } & MIC & $0.10 \pm 0.02$ & $0.10 \pm 0.02$ & $0.10 \pm 0.02$ & $0.05 \pm 0.02$ & $0.05 \pm 0.02$ & $0.10 \pm 0.02$ & $0.10 \pm 0.01$ & $0.10 \pm 0.02$ & $0.10 \pm 0.02$ & $0.0002 \pm 0.0000$ \\
\hline & MFC & $0.10 \pm 0.02$ & $0.10 \pm 0.02$ & $0.10 \pm 0.02$ & $0.10 \pm 0.01$ & $0.10 \pm 0.02$ & $0.10 \pm 0.02$ & $0.10 \pm 0.02$ & $0.10 \pm 0.02$ & $0.10 \pm 0.02$ & $0.0010 \pm 0.0002$ \\
\hline
\end{tabular}

483 * apigenin (1), cynarasaponins $\mathrm{A}+\mathrm{H}$ (2), luteolin 7-glucoside (3), apigenin 7-rutinoside (4), luteolin (5), chlorogenic acid (6), $\beta$ 484 sitosterol (7), cynarasaponins B+K (8) and apigenin 7-glucoside (9) 